\title{
Two new charismatic Pristimantis species (Anura: Craugastoridae) from the tepuis of "The Lost World" (Pantepui region, South America)
}

\author{
Philippe J. R. KOK ${ }^{1,2}$ \\ ${ }^{1}$ Department of Vertebrates, Royal Belgian Institute of Natural Sciences, rue Vautier 29, B-1000 \\ Brussels, Belgium \\ E-mail: philippe.kok@naturalsciences.be \\ ${ }^{2}$ Amphibian Evolution Lab, Department of Biology, Vrije Universiteit Brussel, Pleinlaan 2, B-1050 \\ Brussels, Belgium \\ E-mail: philippe.kok@vub.ac.be \\ urn:Isid:zoobank.org:author:62BA0CB3-FB94-407F-90A1-06AB6401B911
}

\begin{abstract}
Two new colourful species of direct-developing frogs of the genus Pristimantis are described from the summit of two isolated tepuis (sandstone table mountains) in the Eastern Pantepui District of the Guiana Shield highlands. Pristimantis jamescameroni sp. nov. is described from the summit of Aprada-tepui from 2557-2571 m elevation, and P. imthurni sp. nov. is described from the summit of Ptaritepui at $2471 \mathrm{~m}$ elevation. Both species share the absence of a differentiated tympanic membrane and external tympanic annulus (but presence of tiny pharyngeal ostia), the presence of nuptial pads in males, and the presence of lateral fringes on fingers and toes, a combination of characters that immediately distinguishes them from all other known Pantepui congeners. The two new species are morphologically similar to each other and are phylogenetically closely related, but they can be distinguished based on colour pattern and morphological characters such as head proportions, dorsal skin texture, and condition of the supratympanic fold. The IUCN conservation status of the new species is considered as Endangered (EN) owing to their apparent very restricted ranges. The number of described Pristimantis species occurring exclusively on tepui (and faunistically related granitic mountains) summits and upper slopes now reaches eleven.
\end{abstract}

Keywords. Anura, Guiana Shield, Systematics, Taxonomy, Terrarana.

Kok P.J.R. 2013. Two new charismatic Pristimantis species (Anura: Craugastoridae) from the tepuis of "The Lost World" (Pantepui region, South America). European Journal of Taxonomy 60: 1-24. http://dx.doi.org/10.5852/ ejt.2013.60

\section{Introduction}

The outstanding biogeographic region where the tepuis (a word used to describe South American table mountains consisting of Precambrian sandstone) and the faunistically related granitic mountains occur, was named Pantepui by Mayr \& Phelps (1967) in their seminal study on the origin of the bird fauna of the south Venezuelan highlands. The Pantepui region (Fig. 1A) lies in the northwestern part of the Guiana Shield and is traditionally seen as one of the foremost centres of endemism in the Neotropics (Berry et al. 1995; Davis et al. 1997). Historically, Pantepui has often been limited to the upper slopes and summits 


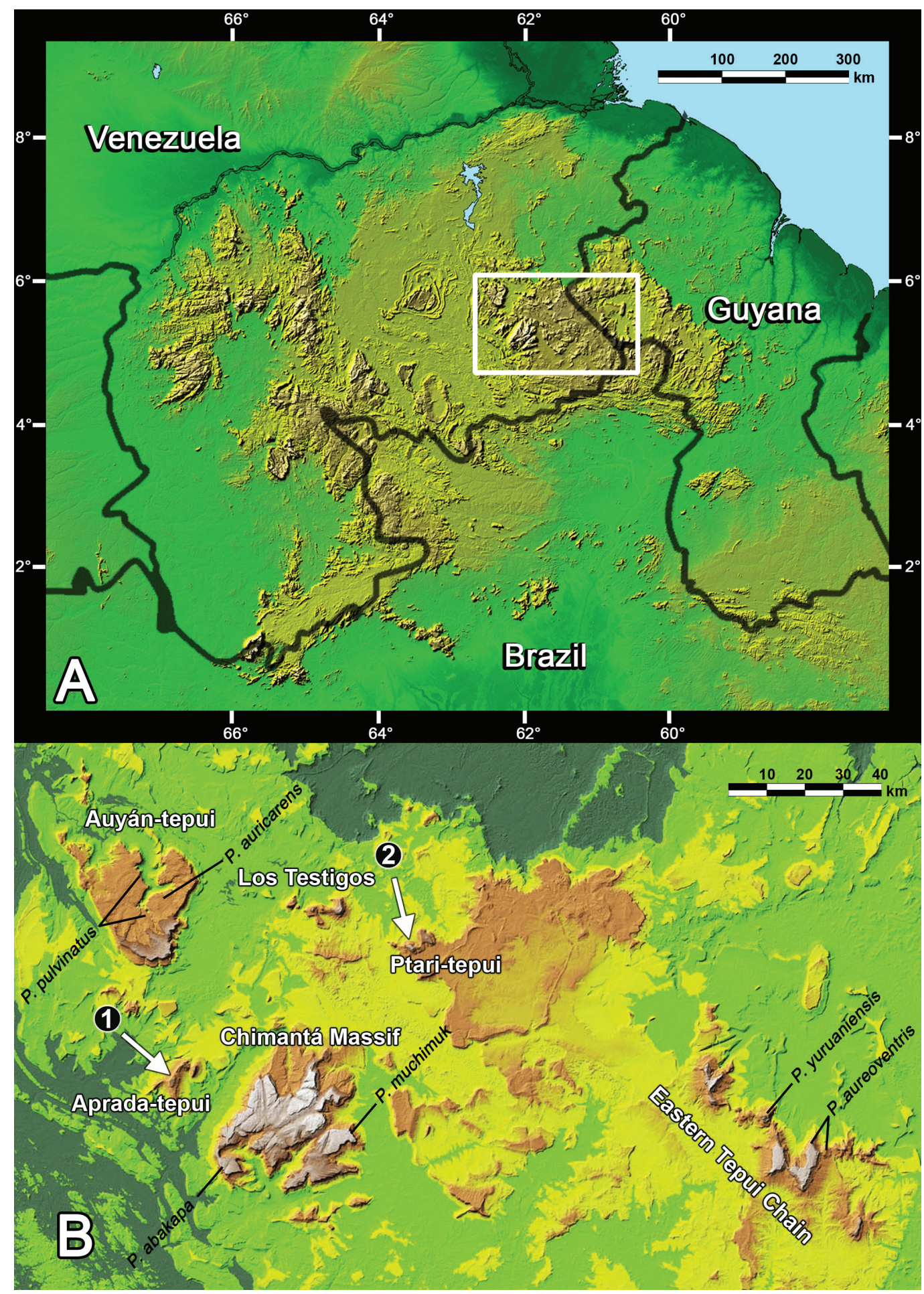

Fig. 1. A. Map of the Pantepui region, located in the western part of the Guiana Shield. The white rectangle corresponds to the area enlarged in (B). B. Distribution of known tepui summit Pristimantis species occurring east of the Rio Caroní in Venezuela and in western Guyana: P. aureoventris (WeiAssipu-tepui and upper slopes of Mount Roraima), P. yuruaniensis (Yuruaní-tepui), P. muchimuk (Churí-tepui), P. abakapa (Abakapá-tepui), P. auricarens and P. pulvinatus (Auyán-tepui); (1) Apradatepui, type locality of Pristimantis jamescameroni sp. nov. (area enlarged in Fig. 6A); (2) Ptari-tepui, type locality of Pristimantis imthurni sp. nov. (area enlarged in Fig. 6B). 
of the Guiana Shield highlands covering a total surface of about $5000 \mathrm{~km}^{2}$, with an altitudinal range of 1,500-3,014 m above sea level (Mayr \& Phelps 1967; Rull \& Nogué 2007). Nonetheless, Steyermark (1982), followed by Kok et al. (2012) and Kok (2013), expanded the original definition of Pantepui to include the intervening Pantepui lowlands (200-400 m asl) and uplands (400 - ca. $1200 \mathrm{~m}$ asl), which better reflects the biogeography and the past and current biotic interactions in the area (Kok 2013).

The Scottish writer Sir Arthur Conan Doyle was the first to coin the expression "The Lost World" in the title of his famous fiction novel published in 1912, in which he depicts an extraordinary expedition to an isolated table mountain in the tropical jungle of northern South America in search of dinosaur-like creatures and a forgotten civilisation (Doyle 1912). Doyle was largely inspired by the account of an expedition of the Royal Geographical Society of London to the summit of Mount Roraima in 1884, led by Sir Everard im Thurn (McDiarmid \& Donnelly 2005; Dalziell 2007).

The vertical walls of tepuis can reach $1000 \mathrm{~m}$, which makes most of these mountains isolated horizontally from one another, but also vertically from their surroundings. In addition to physiographic isolation, current edaphic, climatic and ecological factors contribute to further isolate most tepui tops from the surrounding savannah and tropical forest.

Kok et al. (2012) demonstrated that, despite their current unique geomorphology, the tepuis were insufficient barriers to local (i.e., within Pantepui) gene flow, leading to a low genetic diversity among most tepui summit amphibians and reptiles. The same authors suggested that single-tepui endemism might not be as common as previously stated, since some tepui summit species, described as being singletepui endemics, turned out to be synonyms of more widespread taxa (e.g., in the genera Anomaloglossus and Tepuihyla, see for instance Kok et al. 2013 and Jungfer et al. 2013). Evolutionary processes in the area remain puzzling given that on the one hand, species previously reported as highly restricted often also occur on nearby tepuis, or in some cases in the surrounding uplands (Tepuihyla), and on the other hand, some populations occurring on different tepui summits and identified as a single species turned out to be complexes of distinct taxa phenotypically hard to distinguish from one another (e.g., in the genus Stefania, Kok pers. obs.). Kok et al's (2012) discovery has a potentially strong implication for the taxonomic status of several described tepui species and highlights the difficulty of taxonomic decisions in the region, which until now was often strongly influenced by the unique topography of the area, and probably also by the legacy of Doyle's novel. However, from a conservation point of view it is crucial to delimitate species and species' distributions as accurately as possible, especially in these mountainous areas reported as particularly sensitive to global warming (Nogué et al. 2009).

The frog genus Pristimantis is the most speciose vertebrate genus, with more than 450 nominal species currently recognized (Frost 2013). Twenty of these described species are distributed in Pantepui (Kok \& Barrio-Amorós 2013; Rojas-Runjaic et al. 2013), nine of them stated as being restricted to tepui summits and tepui upper slopes (sensu Kok 2013; Rojas-Runjaic et al. 2013). These numbers do not include the many putative undescribed and highly restricted species (at least 15), reported from the region by McDiarmid \& Donnelly (2005) and still waiting to be named.

New material was recently obtained from several poorly explored tepuis, which confirms the occurrence of two distinct, unnamed Pristimantis species on Aprada-tepui and Ptari-tepui, respectively, two isolated tepuis located east of the Río Caroní, in the Eastern Pantepui District, Bolívar state, Venezuela. These new species are described below and their IUCN Red List Category is discussed. 


\section{Material and methods}

\section{Fieldwork and deposition of specimens}

Tepui summits harbour fragile ecosystems and extreme care was taken to ensure a minimum impact on the environment (e.g., no waste was left, vegetation was not damaged and turned rocks were replaced as they were found whenever possible). Specimens were collected by hand and euthanized by immersion in a $2 \%$ lidocaine solution (Linisol), fixed in 10\% formalin for a few days and transferred to $70 \%$ ethanol for permanent storage. A piece of liver and/or thigh muscle was taken from most specimens prior to fixation and preserved in 95\% ethanol for later molecular analyses. Specimens were deposited in the collections of the Institut Royal des Sciences Naturelles de Belgique (IRSNB). Tissue samples were deposited in the Amphibian Evolution Lab, Biology Department at the Vrije Universiteit Brussel (VUB). Coordinates and elevations of the collection localities were acquired using a Garmin Global Positioning System unit and referenced to map datum WGS84.

\section{Morphology}

Terminology for morphological characters mostly follows Lynch \& Duellman (1997), Savage et al. (2004), Kok \& Kalamandeen (2008), Means \& Savage (2007), Duellman \& Lehr (2009), and Kok et al. (2011). All morphometric data were taken from the preserved specimens to the nearest $0.01 \mathrm{~mm}$ and rounded to the nearest $0.1 \mathrm{~mm}$, under a Leica stereo dissecting microscope using an electronic digital calliper. For ease of comparison, descriptions mainly follow the pattern of recent descriptions in the genus (e.g., Myers \& Donnelly 2008; Barrio-Amorós et al. 2010; Kok et al. 2011; Rojas-Runjaic et al. 2013).

Classical measurements for the genus were taken and are abbreviated as follows:

$\mathrm{EL}=$ eye length, horizontal distance from the posterior margin to the anterior margin of the eye

$\mathrm{EN} \quad=$ eye to naris distance from anterior corner of eye to posterior margin of naris

$\mathrm{FL}=$ foot length from proximal edge of outer metatarsal tubercle to tip of Toe IV

HAND I = length of Finger I from proximal edge of palmar tubercle to tip of finger

HAND II = length of Finger II from proximal edge of palmar tubercle to tip of finger

HAND III = length of Finger III from proximal edge of palmar tubercle to tip of finger, also equivalent to hand length

HAND IV = length of Finger IV from proximal edge of palmar tubercle to tip of finger

$\mathrm{HL}=$ head length from angle of jaw to tip of snout

HW $\quad=$ greatest width of the head

IN $=$ internarial distance, taken between the median margins of the nares

IO $=$ interorbital distance, taken between the inner margins of the orbits

SL $=$ snout length from anterior corner of eye to tip of snout

SVL $=$ snout-vent length, from tip of snout to posterior margin of vent

TIL = tibia length from outer edge of flexed knee to heel

WFD $\quad=$ width of disc on Finger III

WTD $=$ width of disc on Toe IV

Colour pattern in life was taken from field notes and was later refined based on high definition colour digital photographs. Sex and maturity were determined by dissection and direct examination of gonads, and by examination of secondary sexual characters (such as nuptial pads in males). Internal soft anatomy was examined by dissection of preserved specimens.

Taxonomy follows Pyron \& Wiens (2012). Institutional acronyms follow Frost (2013). 


\section{Results}

\section{Generic allocation of the new species}

No identifiable morphological synapomorphy supporting the genus Pristimantis (Hedges et al. 2008) has been proposed yet. The new taxa are assigned to the genus Pristimantis based on molecular phylogenetic relationships (Kok et al. 2012, Kok pers. obs., August 2012) as well as on their morphological characteristics, which fall within the range of other Pristimantis species (see diagnoses).

Class Amphibia Gray, 1825

Order Anura Fischer von Waldheim, 1813

Family Craugastoridae Hedges, Duellman \& Heinicke, 2008

Subfamily Pristimantinae Pyron \& Wiens, 2011

Pristimantis jamescameroni sp. nov.

Figs 2-5, Table 1

urn:1sid:zoobank.org:act:67EB6C36-0F31-4587-9805-3136BEF4E010

Eleutherodactylinae series b (in part) - Gorzula \& Señaris 1999: 55 + plate 46.

Eleutherodactylus sp. B - McDiarmid \& Donnell, 2005: 514 [table 18A.1], 524.

Pristimantis sp. - Hedges et al. 2008: 179.

Pristimantis sp. "Aprada" - Kok et al. 2012: Suppl. Information: 13.

\section{Definition and diagnosis}

A small species of the genus Pristimantis currently not assigned to any species group, but morphologically most similar to species of the polyphyletic unistrigatus species group (sensu Hedges et al. 2008, see also discussion in Kok et al. 2011) mainly characterized in having Finger I shorter than II, Toe V longer than III, extending to the distal edge of the distal subarticular tubercle of Toe IV when toes are adpressed, and by the absence of cranial crests and the presence of vomerine teeth. The new species is characterized by the following unique combination of characters: (1) body small, male $22.8 \mathrm{~mm}$ SVL, females 26.3-27.5 mm ( $\mathrm{n}=3)$; (2) dorsal skin shagreen, belly skin coarsely areolate; (3) tympanum absent (tympanic membrane not differentiated and tympanic annulus not visible externally); (4) tiny pharyngeal ostia present; (5) snout rounded to subovoid in dorsal view, rounded to slightly sloping in profile, canthus rostralis nearly straight in dorsal view, rounded in cross section, loreal region slightly concave, flaring slightly at upper lip; (6) upper eyelid shagreen with 1-2 distinctly enlarged tubercles on each eyelid; (7) choanae small, oval, dentigerous processes of vomers very small, barely visible, slightly oblique, ovoid to triangular, posterior and medial to choanae, each bearing 1-5 teeth; (8) absence of vocal slits in male; (9) tongue cordiform; (10) two large, mostly unpigmented nuptial pads on each thumb in male; (11) Finger I shorter than II; (12) fingers with lateral fringes, best developed preaxially on Fingers II-III; (13) ulnar tubercles absent or inconspicuous, when present low, not forming a distinct line; (14) tarsal tubercles absent, one inconspicuous calcar tubercle present; (15) inner metatarsal tubercle oval, about four times the size of the round, projecting outer metatarsal tubercle; (16) Toe V longer than III, extending to the distal edge of the distal tubercle on Toe IV when toes are adpressed; (17) toes with lateral fringes, best developed preaxially on Toes III-IV, webbing basal between Toes IV-V; (18) in life main dorsal background colouration is orange to orangish dark brown, either with irregular dark brown chevrons or a darker middorsal band, and/or a light middorsal stripe, ventral colouration is white with brown reticulation and an orange patch posteriorly; (19) in preservative dorsal background colouration is light to dark brown, either with irregular brown chevrons or a darker middorsal band, and/or a light middorsal stripe, ventral colouration is cream with brown reticulation. 


\section{Etymology}

The specific epithet is a noun in the genitive case, honouring the Canadian film director, producer, environmentalist and explorer Mr. James F. Cameron in recognition of his efforts to alert the general public to environmental problems through pioneering high quality "blockbuster" movies and adventurous documentaries. James Cameron also encourages people to go vegan (a diet excluding animal products), one of the effective ways to reduce human environmental impacts such as global climate change, identified as a serious threat to tepuis ecosystems (see Nogué et al. 2009).

\section{Material examined}

\section{Holotype}

VENEZUELA: an adult male collected by Philippe J. R. Kok, 15 Jun. 2012 at $08 \mathrm{~h} 18$, summit of Apradatepui, Bolívar state, $5^{\circ} 24^{\prime} 42^{\prime \prime} \mathrm{N}, 62^{\circ} 27^{\prime} 00^{\prime \prime} \mathrm{W}, 2570$ m elevation, IRSNB 4160 (field number PK 3636).

\section{Paratopotypes $(\mathrm{n}=4)$}

VENEZUELA: three adult females (IRSNB 4161-63, field numbers PK 3632, PK 3637, PK 3635) and one juvenile (IRSNB 4164, field number PK 3639), collected by Philippe J. R. Kok (except IRSNB 4161, collected by Brad Wilson) 14-15 Jun. 2012, all from the summit of Aprada-tepui between 2557$2571 \mathrm{~m}$ elevation.

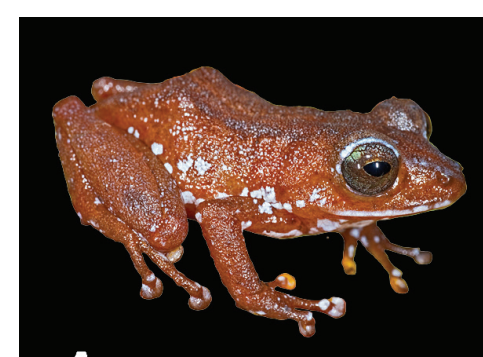

A

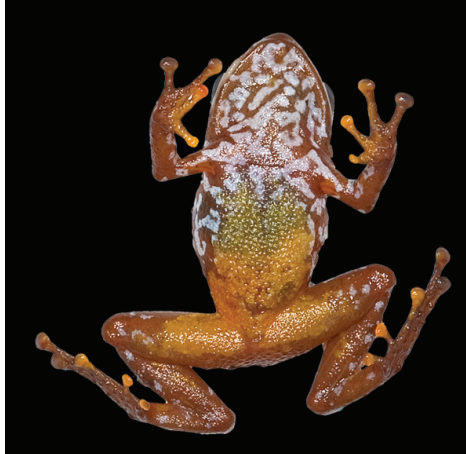

B

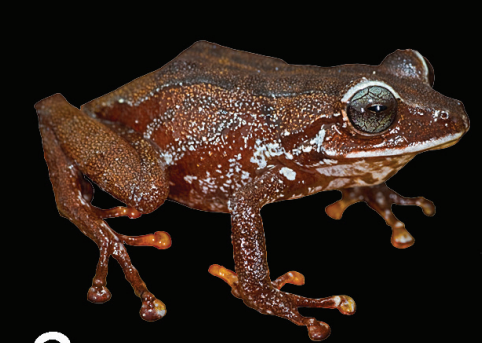

C

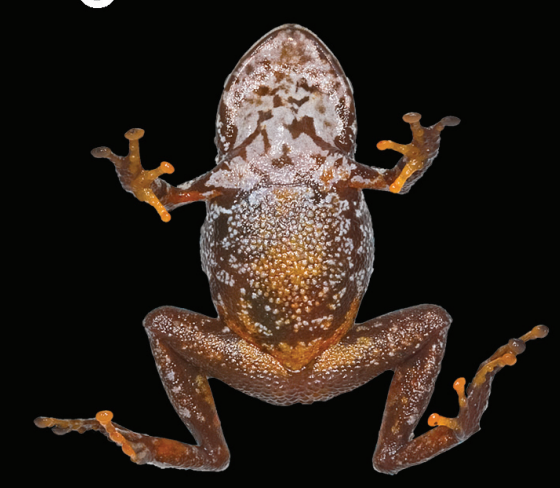

D

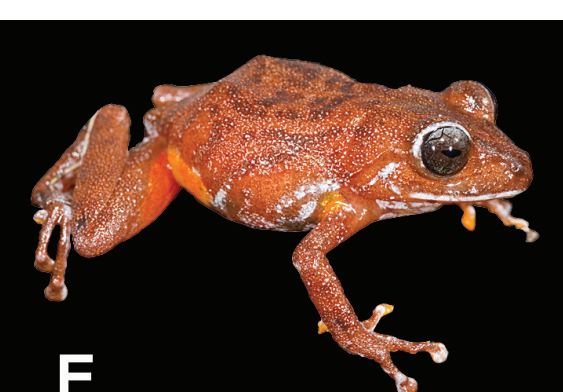

E

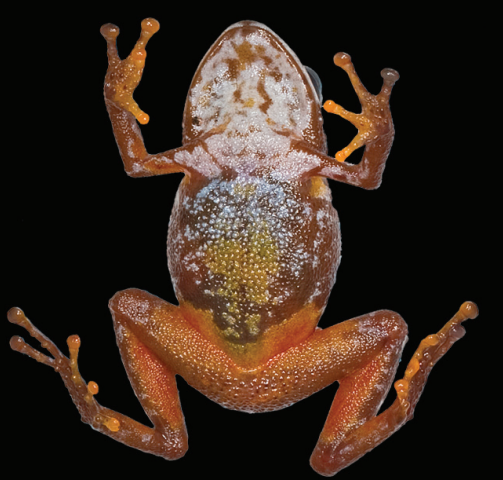

$\mathbf{F}$

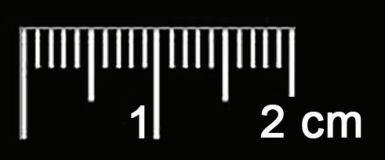

Fig. 2. Pristimantis jamescameroni sp. nov. Intraspecific variation in dorsal and ventral colour pattern in living specimens. A. Dorsolateral view of the $\sigma^{\lambda}$ holotype (IRSNB 4160). B. Ventral view of the same specimen. C. Dorsolateral view of a $q$ paratype (IRSNB 4163). D. Ventral view of the same specimen. E. Dorsolateral view of a $q$ paratype (IRSNB 4162). F. Ventral view of the same specimen. Photographs by the author. 


\section{Description of the holotype}

An adult male $22.8 \mathrm{~mm}$ SVL (Figs 2A-B, 3, 4D, H, see Table 1 for measurements), in very good condition, except a large scar under the right thigh where a piece of muscle was removed prior to preservation. Head slightly longer than wide (HW 94.7\% of HL), wider than body; HW 39.0\% of SVL; HL $41.2 \%$ of SVL; cranial crests absent. Snout longer than eye length (SL 117.1\% of EL), rounded to subovoid in dorsal view, rounded to slightly sloping in profile; canthus rostralis nearly straight in dorsal view, rounded in cross section, loreal region slightly concave, flaring slightly at upper lip; eye-naris distance shorter than eye length (EN $71.4 \%$ of EL). Nares slightly protuberant, directed posterolaterally, visible in frontal and dorsal views. Widest upper eyelid width narrower than interorbital distance (upper eyelid width $82.7 \%$ of IO), upper eyelid shagreen with 1-2 enlarged tubercles on each eyelid. Tympanum absent (tympanic membrane not differentiated and tympanic annulus not visible externally); tiny pharyngeal ostia present. Supratympanic fold conspicuous in life, slightly arched, originating at posterior corner of eye, failing to reach shoulder; post-rictal tubercles evident. Choanae small, oval, not concealed by palatal shelf of maxillary arch; dentigerous processes of vomers very small, barely visible, slightly oblique, ovoid to triangular, posterior and medial to choanae, each bearing 3-4 teeth. Tongue cordiform, slightly longer than wide, rounded posteriorly, posterior half free. Vocal slits and vocal sac absent.
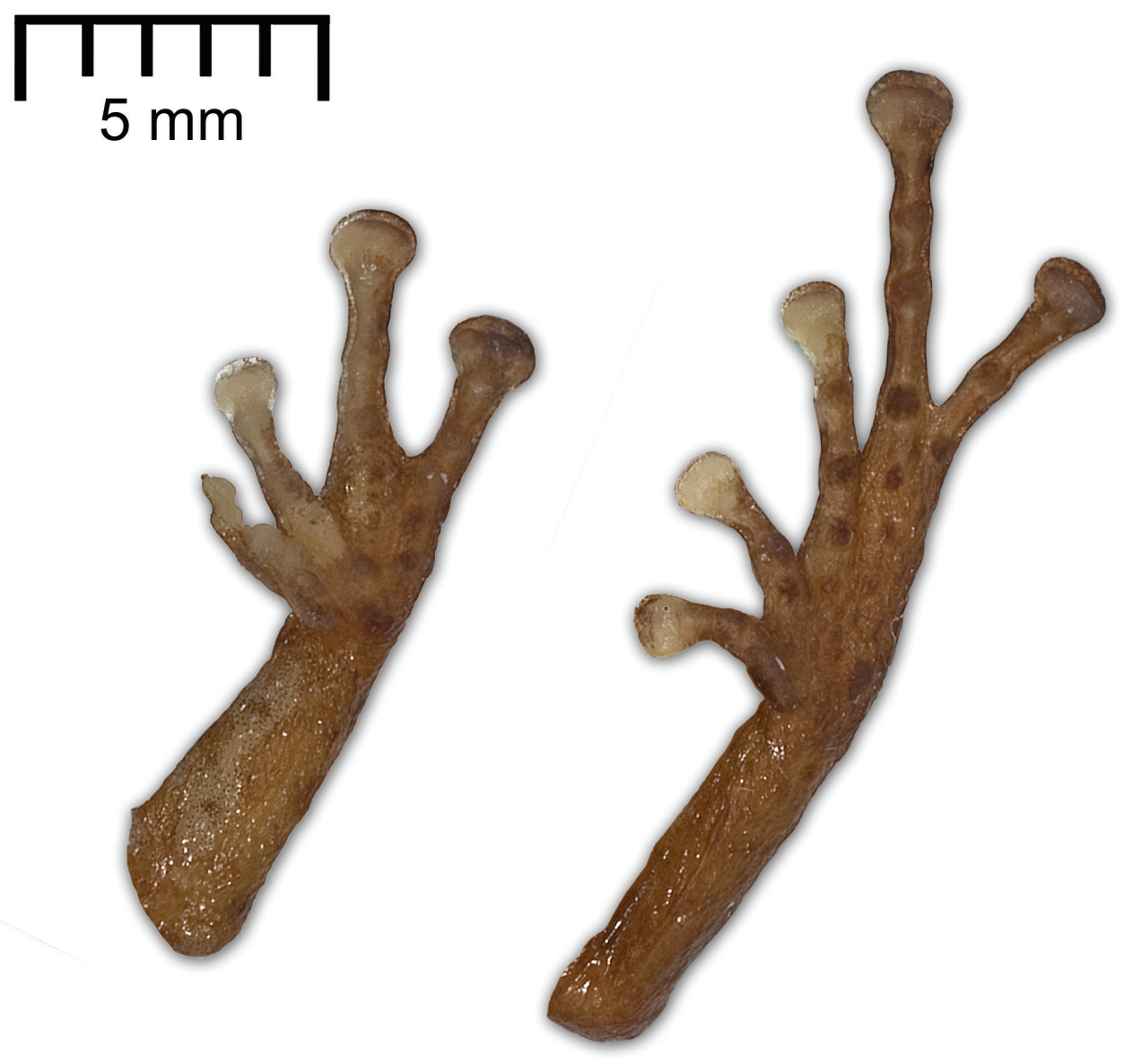

Fig. 3. Pristimantis jamescameroni sp. nov. Ventral view of left hand and left foot of the $\delta$ holotype (IRSNB 4160). Photographs by the author. 

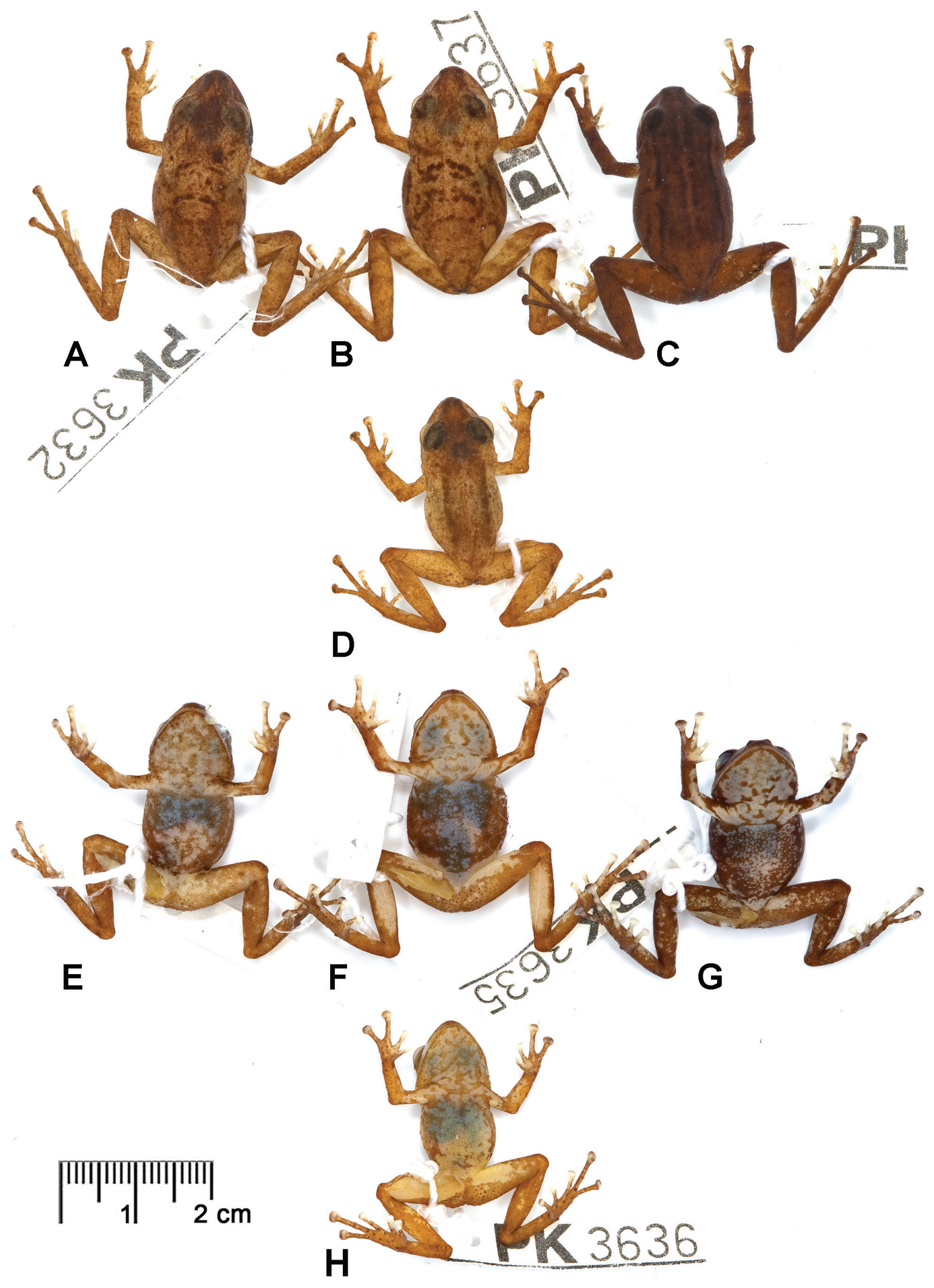

Fig. 4. Pristimantis jamescameroni sp. nov. Intraspecific variation in dorsal (above) and ventral (below) colour pattern in preserved specimens. A, E. $q$ paratype (IRSNB 4161). B, F. + paratype (IRSNB 4162). C, G. + paratype (IRSNB 4163). D, H. $\sigma^{\lambda}$ holotype (IRSNB 4160). Photographs by the author. 
Dorsal skin shagreen, including on head; middorsal raphe detectable; no dermal folds or ridges visible on dorsal surface; flanks granular. Throat surface shagreen; upper chest shagreen, slightly "wrinkled"; weak thoracic fold; belly skin coarsely areolate; weak discoidal fold anterior to groin; posteroventral thigh and cloacal region coarsely areolate; cloacal sheath absent.

Hand length $27.2 \%$ of SVL. Finger I $80.0 \%$ of II. Relative length of fingers III $>$ IV $>$ II $>$ I; adpressed Finger I fails to reach proximal edge of digital pad of Finger II; adpressed Finger IV reaches the intercalary cartilage of Finger III on the left side, the base of the disc of Finger III on the right side. Two large, not connected, non-spinous, mostly unpigmented (translucent when wet, white when dry) nuptial pads on each thumb, one extending along the preaxial surface of the thenar tubercle and invading most of it, the other one extending along the dorsal and the preaxial surface of the thumb. Lateral fringes on all fingers, best developed preaxially on Fingers II-III (Fig. 3). Finger discs broadly expanded, elliptical, broader than long, circumferential groove conspicuous, distal edge of disc rounded; disc of Finger III 2.1 times wider that the distal end of the adjacent phalanx. Palmar tubercle large, poorly defined, not fully pigmented, deeply bifid; thenar tubercle large, protuberant, ovoid; supernumerary tubercles few, large (almost equal in size to the subarticular tubercles), slightly protuberant; subarticular tubercles large, round and protuberant, one each on FI and FII, two each on FIII and FIV. Ulnar tubercles few, inconspicuous, forming an ill-defined line; presence of a small antebrachial tubercle.

Hind limbs moderate in length, heels slightly overlap when held at right angles to sagittal plane; TIL $50.4 \%$ of SVL; FL $41.7 \%$ of SVL. Relative length of Toes IV $>$ V > III $>$ II $>$ I; tip of Toe V extends to the distal edge of the distal subarticular tubercle on Toe IV; tip of Toe III extends to the distal edge of the penultimate subarticular tubercle on Toe IV on the left side, to the proximal half of the penultimate subarticular tubercle on Toe IV on the right side. Lateral fringes on all toes, best developed preaxially on Toes III-IV; webbing basal between Toe IV-V (Fig. 3). Toe discs mostly equal in size to finger discs, WTD/WFD = 1; toe discs broadly expanded, elliptical, broader than long, circumferential groove conspicuous, distal edge of disc rounded. Inner metatarsal tubercle elongate, oval, about four times the size of the projecting, round outer metatarsal tubercle; subarticular tubercles round, large and protuberant; supernumerary plantar tubercles small, low and round, increasing in size distally. Single, inconspicuous and very small round calcar tubercle; no outer tarsal tubercles detectable; inner tarsal fold not detectable.

\section{Colour of holotype in life (see Fig. 2A-B)}

Dorsal background colour orangish brown covered with numerous tiny white flecks, top of head slightly darker; inconspicuous darker (than adjacent dorsum) middorsal band outlined by ill-defined dark brown dorsolateral lines; irregular white band on the canthus rostralis; bluish white line on outer edge of upper eyelids; upper lips white; most post-rictal tubercles white; enlarged tubercles on eyelids light brown. Flanks orangish brown, with numerous tiny white flecks and some irregular white spots of variable sizes; groins, anterior thighs, and armpits bright orange. Arms and legs coloured as dorsal surfaces, with a few small irregular white spots on upper arms and on the distal part of tarsi. Throat, chest, and lower flanks white with brown anastomosed reticulation; belly and most of the undersurface of thighs bright orange; undersurface of distal thighs, shanks, and tarsi brown with a few small irregular white spots; posterior surface of thighs and cloacal area brown. Upper face of hands and feet orangish brown, except tip of Fingers I-II, which is bright orange, and tip of toes, which is whitish. Palms and soles brown; undersurface of Fingers I-III bright orange, including discs; undersurface of tip of Toes I-III bright orange including discs. Iris silver with dark brown venation and an ill-defined, broad horizontal brownish stripe; greenish silver spot on the posterior upper part of the iris. 
Table 1. Sex, measurements (in mm), and HL/SVL ratio of type specimens of Pristimantis jamescameroni sp. nov. and Pristimantis imthurni sp. nov. Abbreviations are defined in the text.

\begin{tabular}{|c|c|c|c|c|c|c|}
\hline \multirow[b]{2}{*}{ Character } & \multicolumn{5}{|c|}{$\begin{array}{l}\text { Pristimantis jamescameroni sp. nov. } \\
\text { Aprada-tepui }\end{array}$} & \multirow{2}{*}{$\begin{array}{c}\begin{array}{c}\text { Pristimantis imthurni sp. nov. } \\
\text { Ptari-tepui }\end{array} \\
\text { IRSNB } 4165\end{array}$} \\
\hline & $\begin{array}{l}\text { IRSNB } \\
4160\end{array}$ & $\begin{array}{l}\text { IRSNB } \\
4161\end{array}$ & $\begin{array}{l}\text { IRSNB } \\
4162\end{array}$ & $\begin{array}{l}\text { IRSNB } \\
4163\end{array}$ & $\begin{array}{l}\text { IRSNB } \\
4164\end{array}$ & \\
\hline Sex & Male & Female & Female & Female & Juvenile & Male \\
\hline SVL & 22.8 & 27.0 & 27.5 & 26.3 & 18.3 & 22.9 \\
\hline $\mathrm{HL}$ & 9.4 & 10.9 & 11.2 & 10.9 & 8.0 & 8.7 \\
\hline HL/SVL & $41.2 \%$ & $40.3 \%$ & $40.7 \%$ & $41.4 \%$ & $43.7 \%$ & $38.0 \%$ \\
\hline HW & 8.9 & 10.1 & 10.3 & 9.9 & 7.4 & 8.5 \\
\hline SL & 4.1 & 4.5 & 4.7 & 4.3 & 3.3 & 3.7 \\
\hline EN & 2.5 & 2.9 & 2.9 & 2.7 & 2.0 & 2.4 \\
\hline IN & 2.1 & 2.5 & 2.4 & 2.5 & 2.1 & 2.3 \\
\hline EL & 3.5 & 3.3 & 3.4 & 3.2 & 2.1 & 3.3 \\
\hline $\mathrm{IO}$ & 2.6 & 2.9 & 2.9 & 3.0 & 2.4 & 2.7 \\
\hline HAND I & 3.6 & 4.2 & 4.2 & 4.0 & 3.1 & 3.9 \\
\hline HAND II & 4.5 & 4.7 & 4.5 & 5.1 & 3.4 & 4.4 \\
\hline HAND III & 6.2 & 6.7 & 6.6 & 6.6 & 4.8 & 6.2 \\
\hline HAND IV & 4.8 & 5.3 & 4.9 & 5.6 & 3.7 & 4.9 \\
\hline WFD & 1.3 & 1.3 & 1.3 & 1.4 & 1.0 & 1.3 \\
\hline FL & 9.5 & 10.5 & 10.4 & 10.6 & 7.4 & 9.3 \\
\hline WTD & 1.3 & 1.3 & 1.5 & 1.5 & 1.0 & 1.4 \\
\hline TIL & 11.5 & 13.2 & 12.7 & 12.8 & 9.9 & 11.5 \\
\hline
\end{tabular}

Colour of holotype in preservative (see Fig. 4D, H)

After 13 months in 70\% ethanol (July 2013), orangish brown faded to light brown. Orange and white faded to cream. Dorsal pattern turned generally more conspicuous. Brown reticulation on throat, chest, and lower flanks faded to light brown. Granules in the cloacal area, as well as subarticular and supernumerary tubercles became dark brown. Discs are greyish brown.

\section{Sexual dimorphism and variation among paratypes}

See Table 1 for measurements of the type series, and Figs 2, 4, 5 for intraspecific variation. Sexual dimorphism evident in size, with adult females being larger than the adult male (26.3-27.5 vs. $22.8 \mathrm{~mm}$ SVL), and by the presence of two nuptial pads in the male. A sexual dichromatism in belly colouration seems to occur, with the presence of an orange spot restricted to the middle area of the belly in living females, whereas the orange area covers the belly, the posterior part of the ventral surface, and the undersurface of thighs in a more continuous way in the living male (see Fig. 2B, D, F). Hands and feet slightly longer in the male than in the females (HAND III $27.2 \% v s .24 .0-25.1 \%$ of SVL; FL $41.7 \% v s$. $37.8-40.3 \%$ of SVL). No additional significant difference is detected in other size ratios. No significant variation in skin texture occurs among the preserved specimens, but in life IRSNB 4163 (adult female, Fig. 2C) had a conspicuous dorsolateral fold extending from behind the eye to the end of the body; that fold totally disappeared in preservative. Eyelid tubercles are more difficult to detect in preserved specimens and range from 1 to 2 on each eyelid. Number of teeth on dentigerous processes of vomers 
varies from 2 to 6 . Weak thoracic and discoidal folds detectable in IRSNB 4163 (female) and IRSNB 4164 (juvenile), not seen in the other paratypes. Tip of Toe $\mathrm{V}$ fails to reach the distal edge of the distal subarticular tubercle on Toe IV on the left side in IRSNB 4161 (female) only.

Colour pattern variable. In life, dorsal background colouration varies from bright orange to orangish dark brown, usually covered with tiny white flecks; dorsal pattern varies from irregular brown chevrons (e.g., in IRSNB 4161 and IRSNB 4162) to a slightly darker (than adjacent dorsum) middorsal band outlined by ill-defined dark brown dorsolateral lines (e.g., in IRSNB 4160) and/or a pale middorsal stripe (e.g., in IRSNB 4163); pattern on flanks varies from a few irregular oblique white (e.g., IRSNB 4163 ) or brown/white (e.g., IRSNB 4162) stripes to white spots (holotype); colour of ventral reticulation varies from brown to dark brown; inconspicuous transverse bands on arms and legs occur in two female paratypes (IRSNB 4162 and IRSNB 4163). Enlarged tubercles on eyelids are usually white (light brown in the holotype). The juvenile (IRSNB 4164, Fig. 5) has a complex and more marked dorsal pattern consisting of a greyish brown interorbital line preceded by a greyish brown circle and followed by a wide $\mathrm{W}$-shaped marking outlined by greyish brown in the scapular region; the $\mathrm{W}$-shaped marking is followed by a greyish brown arch, itself followed by two back to back C-shaped light grey lines. It also differs from adults in having an irregular greyish band on the canthus rostralis, the upper lip not completely white, granules in the loreal region, dark brown labial stripes, the supratympanic fold underlined by a dark brown band, brown transverse bands on the forearm, and reddish transverse bands on the legs. Iris varies from silver or greenish silver to bronze, with dark brown venation and an illdefined, broad horizontal brownish stripe.

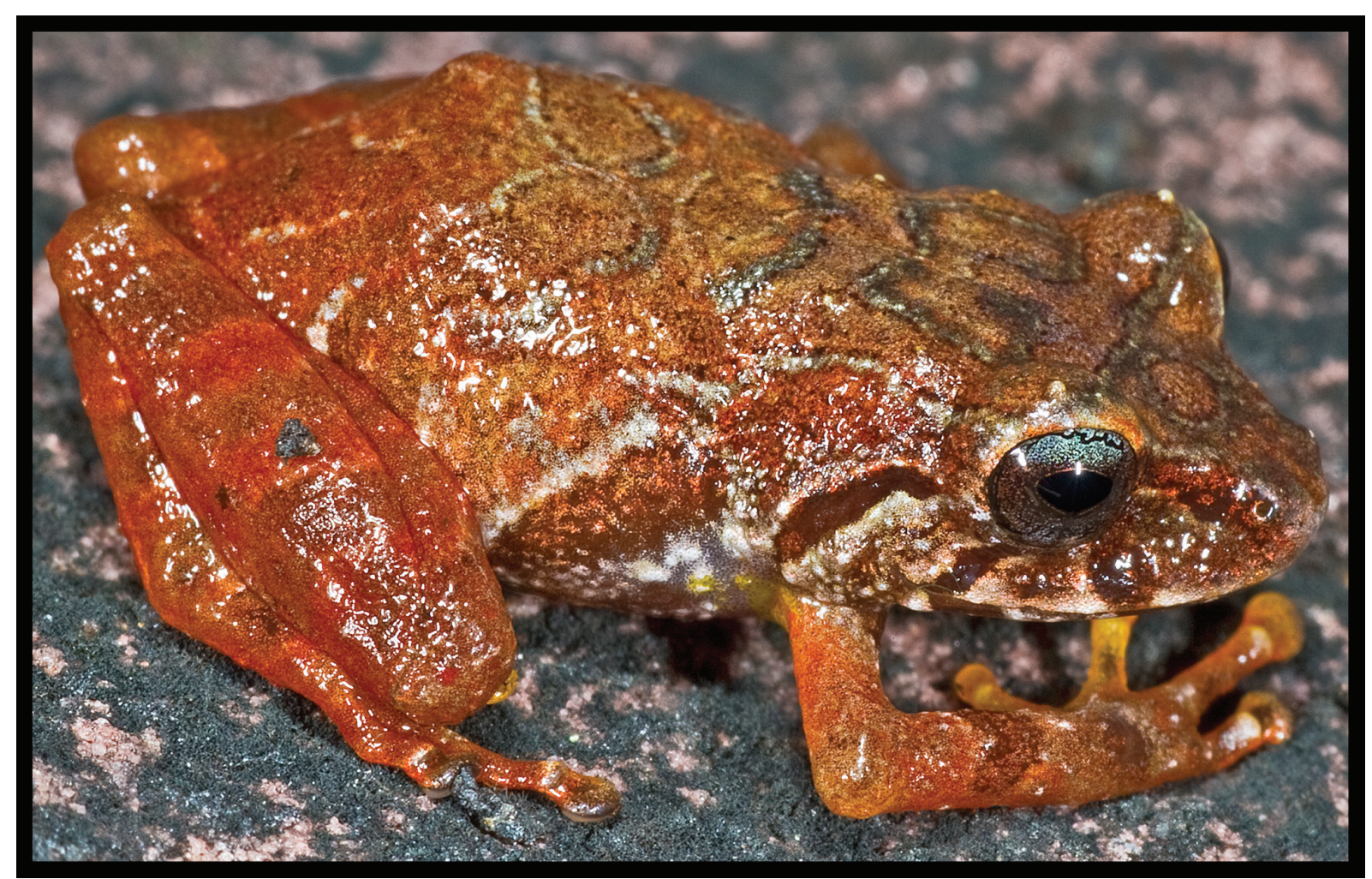

Fig. 5. Pristimantis jamescameroni sp. nov. Juvenile specimen (IRSNB 4164, $18.3 \mathrm{~mm}$ SVL). Photograph by the author. 




Fig. 6. A. Satellite map of the Aprada massif, showing the location of Aprada-tepui and neighbouring smaller table mountains. Yellow star indicates the type locality of Pristimantis jamescameroni. B. Satellite map of the Ptari massif, showing the location of Ptari-tepui and neighbouring mountains. Yellow star indicates the type locality of Pristimantis imthurni. Satellite maps (C) Google Maps. 


\section{Morphological comparisons with congeneric species}

Available data suggest that tepui summit Pristimantis species have relatively restricted distributions in the Guinea Shield highlands; therefore, comparisons with congeners only focus on Pristimantis species known to occur in the Pantepui region (as defined by Kok 2013). Comparisons of external character states are based both on original descriptions and examination of museum specimens (see Appendix for material examined).

Twenty species of Pristimantis are currently reported from the Pantepui region: P. aureoventris Kok, Means \& Bossuyt, 2011, only known from the summit of Wei-Assipu-tepui and the upper slopes of Mount Roraima, Cuyuni-Mazaruni District, Guyana; P. abakapa Rojas-Runjaic, Salerno, Señaris \& Pauly, 2013, described from the summit of Abakapá-tepui, Bolívar state, Venezuela; P. auricarens (Myers \& Donnelly, 2008), known only from Auyán-tepui, Bolívar state, Venezuela; P. avius (Myers \& Donnelly, 1997), reported from Pico Tamacuari, Amazonas state, Venezuela; P. cantitans (Myers \& Donnelly, 1996), known from Cerro Yaví and Cerro Yutajé, Amazonas state, Venezuela; P. dendrobatoides Means \& Savage, 2007, only known from the Wokomung massif, Potaro-Siparuni District, Guyana; P. guaiquinimensis (Schlüter \& Rödder, 2007), described from Guaiquinima-tepui, Bolívar state, Venezuela; P.jester Means \& Savage, 2007, known from the Wokomung massif, Potaro-Siparuni District, Guyana, and the slopes of Maringma-tepui, Cuyuni-Mazaruni District, Guyana (Kok, pers. obs. 2007); P. marahuaka (Fuentes-Ramos \& Barrio-Amorós, 2004), endemic to Cerro Marahuaka, Amazonas state, Venezuela; P. marmoratus (Boulenger, 1900), reported as widespread in the Guiana Shield from eastern Venezuela to French Guiana and northern Brazil (Frost 2013), but several species may hide under this name; P. memorans (Myers \& Donnelly, 1997), known only from the Sierra Tapirapecó, Amazonas state, Venezuela; P. muchimuk Barrio-Amorós, Mesa, Brewer-Carías \& McDiarmid 2010, apparently endemic to the summit of Churí-tepui, Bolívar state, Venezuela; P. pruinatus (Myers \& Donnelly, 1996), known only from Cerro Yaví, Amazonas state, Venezuela; P. pulvinatus (Rivero, 1968), reported from the Gran Sabana region and Auyán-tepui, Bolívar state, Venezuela to western Guyana (Frost 2013), but more than one species may hide under this name (see Kok et al. 2012); P. saltissimus Means \& Savage, 2007, known from the Wokomung massif, Potaro-Siparuni District, Guyana, and the slopes of Maringma-tepui, Cuyuni-Mazaruni District, Guyana (Kok pers. obs. 2007); P. sarisarinama BarrioAmorós \& Brewer-Carías, 2008, endemic to Sarisariñama-tepui, Bolívar state, Venezuela; P. vilarsi (Melin, 1941), known from upper Amazonian Brazil, Colombia, Venezuela and Peru (Frost 2013); P. yaviensis (Myers \& Donnelly, 1996), reported from Cerro Yaví and Cerro Yutajé, Amazonas state, Venezuela; P. yuruaniensis Rödder \& Jungfer, 2008, known with certainty only from the summit of Yuruaní-tepui, Bolívar state, Venezuela (possible occurrence on the neighbouring Kukenán-tepui, see Mägdefrau \& Mägdefrau 1994; Rödder \& Jungfer 2008; Kok et al. 2011); and P. zeuctotylus (Lynch \& Hoogmoed, 1977), widespread in northeastern South America (Frost 2013).

Pristimantis jamescameroni sp. nov. is most easily distinguished from $P$. abakapa, $P$. aureoventris, $P$. avius, $P$. cantitans, $P$. dendrobatoides, $P$. guaiquinimensis, $P$. marmoratus, $P$. memorans, $P$. pruinatus, $P$. pulvinatus, $P$. saltissimus, $P$. sarisarinama, $P$. vilarsi, $P$. yuruaniensis and $P$. zeuctotylus by lacking a differentiated tympanic membrane and an external tympanic annulus (at least one of these structures is detectable in the latter 15 species). It further differs from $P$. vilarsi and P. zeuctotylus in having Finger I $<$ II (Finger I $>$ II in P. vilarsi and P. zeuctotylus).

Pristimantis jamescameroni sp. nov. is immediately distinguished from $P$. auricarens, P. jester, $P$. marahuaka, P. muchimuk, and P. yaviensis (the only known Pantepui "earless" Pristimantis) in having conspicuous lateral fringes on fingers and toes (absent or limited to a weak keel in the latter 5 species). 


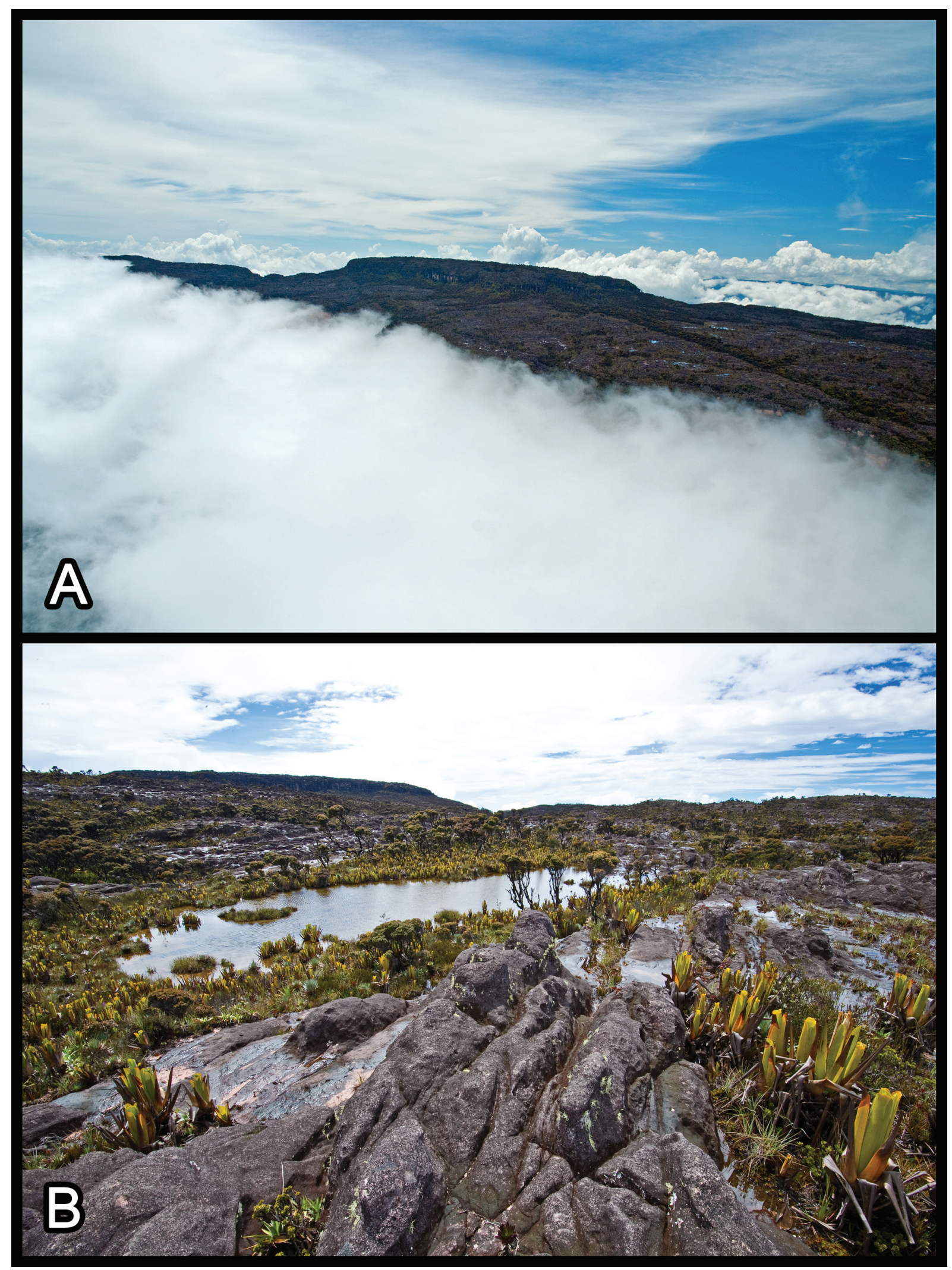

Fig. 7. A. The summit of Aprada-tepui lying above the clouds, photographed from a helicopter looking to the SW (2 May 2011). B. Summit of Aprada-tepui (15 Jun. 2012). Photographs by the author. 


\section{Distribution and ecology}

Pristimantis jamescameroni sp. nov. is only known from the summit of Aprada-tepui (Figs 1B, 6A, 7A-B), Bolívar state, Venezuela, where it occurs from 2557 to $2571 \mathrm{~m}$ elevation. Aprada-tepui lies in the Aprada massif (Fig. 6A), in the Chimantá subdistrict (McDiarmid \& Donnelly 2005). It is located ca. $22 \mathrm{~km} \mathrm{NW}$ of the Chimantá massif and $c a .30 \mathrm{~km} \mathrm{~S}$ of Auyán-tepui (airline). According to the GPS, Aprada-tepui reaches a maximal elevation of about $2575 \mathrm{~m}$ above sea level. The summit area of Aprada-tepui is $c a .4 .3 \mathrm{~km}^{2}$, and is mainly covered by open rock vegetation and small islands of tepui forests (Huber 1995, Fig. 7B); it is characterized by a high number of small lakes (Fig. 7B) and some deep canyons.

Aside from the male holotype, which was collected by day on the ground while calling in a small shallow rock crevice, hidden by the vegetation, all specimens were collected under rocks. Other males were heard calling very sporadically from shallow rock crevices by day, but could not be located. As in most other tepui summit Pristimantis, the new species is not abundant and individuals are difficult to collect. The only other anuran reported from the summit of Aprada-tepui is Stefania satelles Señaris, Ayarzagüena \& Gorzula, 1997, which occurs in higher density and might partly feed on P. jamescameroni sp. nov. (pers. obs.).

Pristimantis imthurni sp. nov.

Figs 8-10, Table 1

urn:1sid:zoobank.org:act:9AFC18C4-23A0-4C20-96EB-480F0F512791

Eleutherodactylus sp. H - McDiarmid \& Donnelly 2005: 514 [table 18A.1], 521.

\section{Definition and diagnosis}

A small species of the genus Pristimantis currently not assigned to any species group, but morphologically most similar to species of the polyphyletic unistrigatus species group (sensu Hedges et al. 2008, see also discussion in Kok et al. 2011) mainly characterized in having Finger I shorter than II, Toe V longer than III, extending to the distal edge of the distal subarticular tubercle of Toe IV when toes are adpressed, and by the absence of cranial crests and the presence of vomerine teeth. The new species is characterized by the following unique combination of characters: (1) body small, male $22.9 \mathrm{~mm}$ SVL; (2) dorsal skin smooth, belly skin coarsely areolate; (3) tympanum absent (tympanic membrane not differentiated and tympanic annulus not visible externally); (4) tiny pharyngeal ostia present; (5) snout broadly rounded in dorsal view and in profile, canthus rostralis nearly straight in dorsal view, rounded in cross section, loreal region concave, flaring slightly at upper lip; (6) upper eyelid smooth with one barely distinct enlarged tubercle; (7) choanae very small, round, dentigerous processes of vomers inconspicuous, ovoid, posterior and medial to choanae, each bearing 3-4 teeth; (8) absence of vocal slits in male; (9) tongue cordiform; (10) two large, broadly connected, mostly unpigmented nuptial pads on each thumb in male; (11) Finger I shorter than II; (12) fingers with lateral fringes, best developed preaxially on Fingers II-III; (13) ulnar tubercles absent; (14) tarsal tubercles absent, one inconspicuous calcar tubercle present; (15) inner metatarsal tubercle oval, about four times the size of the round, projecting outer metatarsal tubercle; (16) Toe V longer than III, extending to the distal edge of the distal tubercle on Toe IV when toes are adpressed; (17) toes with lateral fringes, best developed preaxially on Toes III-IV, webbing basal between Toes IV-V; (18) in life dorsal background colouration is vivid yellow with a chocolate brown middorsal stripe and chocolate brown flanks, ventral colouration is translucent brown with a few white spots and flecks; (19) in preservative dorsal background colouration is pale yellow with a light brown middorsal stripe and light brown flanks, ventral colouration is light grey with a few white spots and flecks. 


\section{Etymology}

The specific epithet is a noun in the genitive case, honouring Sir Everard F. im Thurn (1852-1932), British colonial official, author, explorer, botanist, and photographer. Everard im Thurn was the first to climb a major tepui (Mount Roraima in December 1884), along with British surveyor Harry Perkins, a Pomeroon Amerindian named Gabriel, and five other unnamed Amerindians (Dalziell 2007). Im Thurn's expedition on Roraima and his numerous discoveries were partly eclipsed by the popular novel that they inspired: "The Lost World" by Sir Arthur Conan Doyle (see Introduction; Dalziell 2007).

\section{Material examined}

\section{Holotype}

VENEZUELA: an adult male collected by Philippe J. R. Kok, 20 Jun. 2012 at 20h37, summit of Ptaritepui, Bolívar state, 546’09” N, 6149’02” W, 2471 m elevation, IRSNB 4165 (field number PK 3671).

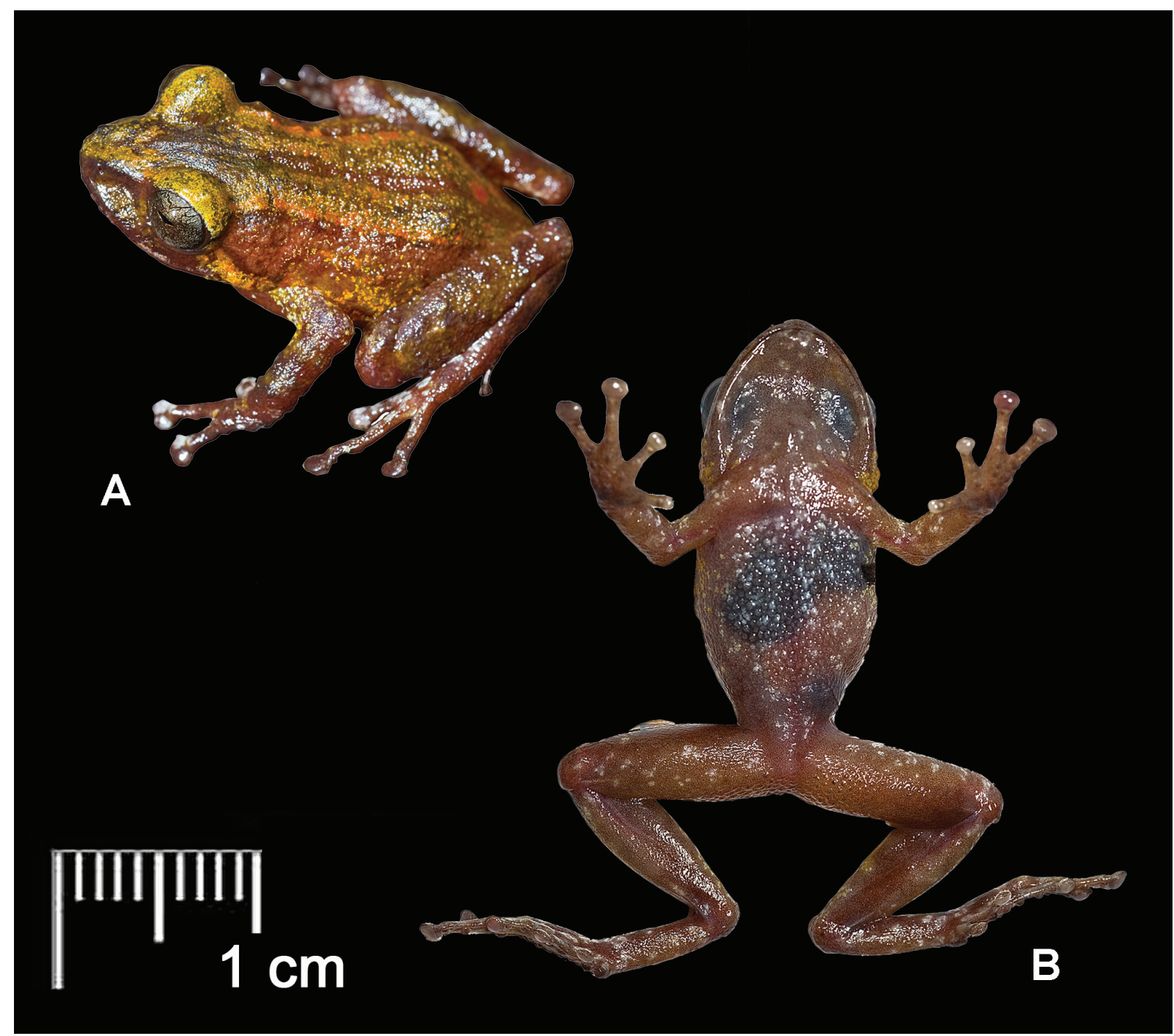

Fig. 8. Pristimantis imthurni sp. nov. in life. A. Dorsolateral view of the $\widehat{\jmath}$ holotype (IRSNB 4165). B. Ventral view of the same specimen. Photographs by the author. 


\section{Morphological comparisons with congeneric species}

For the same reasons mentioned above, comparisons with congeners only focus on the 21 Pristimantis species known to occur in the Pantepui region.

Pristimantis imthurni sp. nov. is most easily distinguished from P. abakapa, P. aureoventris, P. avius, $P$. cantitans, $P$. dendrobatoides, $P$. guaiquinimensis, $P$. marmoratus, $P$. memorans, $P$. pruinatus, $P$. pulvinatus, $P$. saltissimus, $P$. sarisarinama, $P$. vilarsi, $P$. yuruaniensis, and $P$. zeuctotylus by lacking a differentiated tympanic membrane and an external tympanic annulus (at least one of these structures is detectable in the latter 15 species). It further differs from $P$. vilarsi and P. zeuctotylus in having Finger I $<$ II (Finger I > II in P. vilarsi and P. zeuctotylus).

Pristimantis imthurni sp. nov. is immediately distinguished from P. auricarens, P. jester, P. marahuaka, P. muchimuk, and P. yaviensis in having lateral fringes on most fingers and toes (absent or limited to a weak keel in the latter 5 species).

By lacking a differentiated tympanic membrane and an external tympanic annulus, and in having lateral fringes on fingers and toes, Pristimantis imthurni sp. nov. is morphologically most similar to P. jamescameroni sp. nov., described earlier in this paper. These two species are mainly distinguished based on distinct dorsal and ventral colour patterns (compare Fig. 2 with Fig. 8), skin texture (smooth in P. imthurni sp. nov. vs. shagreen in P. jamescameroni sp. nov.), condition of the supratympanic fold (inconspicuous in P. imthurni sp. nov. vs. conspicuous in P. jamescameroni sp. nov.), and head proportion (shorter, with a more rounded snout in $P$. imthurni sp. nov.). Besides being morphologically reliably diagnosable, the two species are currently geographically isolated (isolated lineage segments).

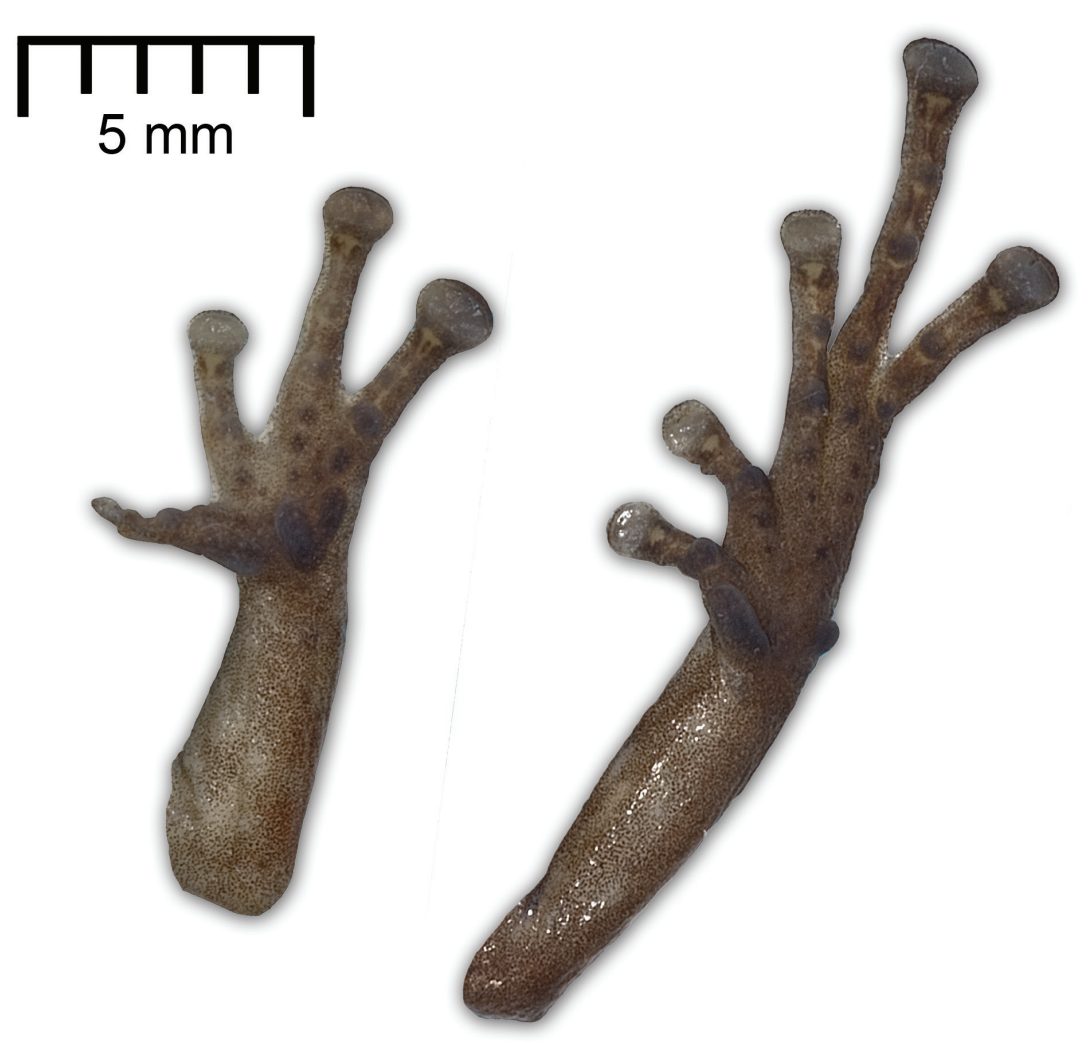

Fig. 9. Pristimantis imthurni sp. nov. Ventral view of left hand and left foot of the $\delta$ holotype (IRSNB 4165). Photographs by the author. 


\section{Description of the holotype}

An adult male $22.9 \mathrm{~mm}$ SVL (Figs 8-10, see Table 1 for measurements), in very good condition, except a large scar under the right thigh where a piece of muscle was removed prior to preservation. Head slightly longer than wide (HW 97.7\% of HL), wider than body; HW 37.1\% of SVL; HL $38.0 \%$ of SVL; cranial crests absent. Snout longer than eye length (SL 112.1\% of EL), broadly rounded in dorsal view and in profile; canthus rostralis nearly straight in dorsal view, rounded in cross section, loreal region concave, flaring slightly at upper lip; eye-naris distance shorter than eye length (EN $72.7 \%$ of EL). Nares slightly protuberant, directed posterolaterally, visible in frontal and dorsal views. Widest upper eyelid width narrower than interorbital distance (upper eyelid width $81.5 \%$ of IO), upper eyelid smooth with one barely visible enlarged tubercle on each eyelid. Tympanum absent (tympanic membrane not differentiated and tympanic annulus not visible externally); tiny pharyngeal ostia present. Supratympanic fold inconspicuous in life, barely visible and fragmented in preservative, slightly arched, apparently originating at posterior corner of eye, failing to reach shoulder; a few low and small post-rictal tubercles. Choanae very small, round; dentigerous processes of vomers inconspicuous, ovoid, posterior and medial to choanae, each bearing 3-4 teeth. Tongue cordiform, slightly wider than long, rounded posteriorly, posterior one-third free. Vocal slits and vocal sac absent.

Dorsal skin smooth, including on head; middorsal raphe barely detectable in preservative, well visible in life; no dermal folds or ridges visible on dorsal surface; flanks slightly granular. Throat and upper chest surfaces smooth; no thoracic fold detectable; belly skin coarsely areolate; no discoidal fold detectable; posteroventral thigh and cloacal region coarsely areolate; cloacal sheath absent, two distinctly enlarged tubercles below cloaca.

Hand length $27.1 \%$ of SVL. Finger I $88.6 \%$ of II. Relative length of fingers III $>$ IV $>$ II $>$ I; adpressed Finger I fails to reach proximal edge of digital pad of Finger II; adpressed Finger IV reaches proximal edge of digital pad of Finger III. Two large, broadly connected, non-spinous, mostly unpigmented (translucent when wet, white when dry) nuptial pads on each thumb, extending from the preaxial surface of the thenar tubercle and invading most of it, along the dorsal and the preaxial surface of the thumb. Lateral fringes on all fingers, best developed preaxially on Fingers II-III (Fig. 9). Finger discs expanded, elliptical, broader than long, circumferential groove conspicuous, distal edge of disc rounded; disc of

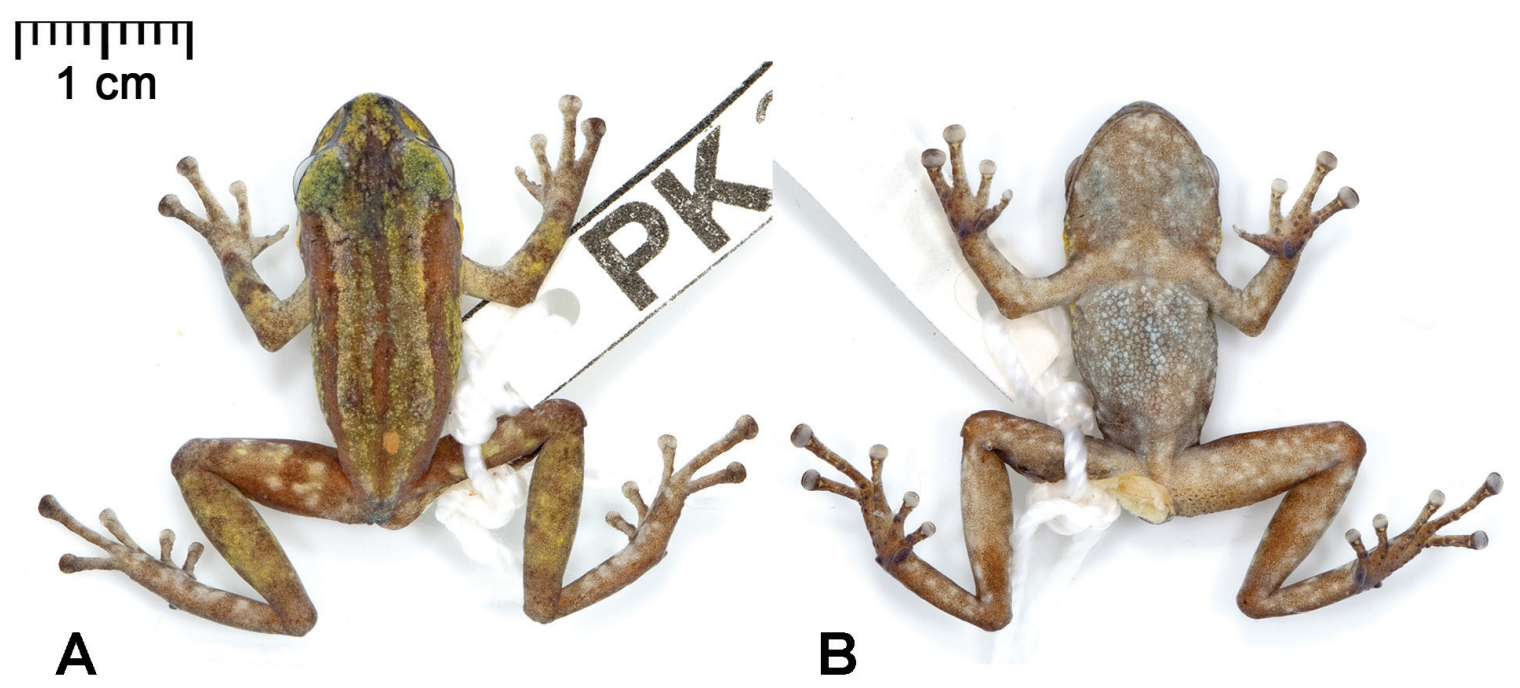

Fig. 10. Pristimantis imthurni sp. nov. in preservative. A. Dorsol view of the ${ }^{1}$ holotype (IRSNB 4165). B. Ventral view of the same specimen. Photographs by the author. 
Finger III 1.8 times wider that the distal end of the adjacent phalanx. Palmar tubercle large, well defined, fully pigmented, deeply bifid; thenar tubercle large, protuberant, ovoid; supernumerary tubercles few, of variable sizes, slightly protuberant; subarticular tubercles large, round and protuberant, one each on FI and FII, two each on FIII and FIV. Ulnar tubercles absent; presence of a small antebrachial tubercle.

Hind limbs moderate in length, heels slightly overlap when held at right angles to sagittal plane; TIL $50.2 \%$ of SVL; FL $40.6 \%$ of SVL. Relative length of Toes IV $>$ V $>$ III $>$ II $>$ I; tip of Toe V extends to the distal edge of the distal subarticular tubercle on Toe IV; tip of Toe III extends to the distal edge of the penultimate subarticular tubercle on Toe IV. Lateral fringes on all toes, best developed preaxially on Toes III-IV (Fig. 9); webbing basal between Toe IV-V. Toe discs slightly larger in size than finger discs, WTD/WFD = 1.08; toe discs expanded, elliptical, broader than long, circumferential groove conspicuous, distal edge of disc rounded. Inner metatarsal tubercle elongate, oval, about four times the size of the projecting, round outer metatarsal tubercle; subarticular tubercles round, large and protuberant; supernumerary plantar tubercles small, low and round, increasing in size distally. Single, inconspicuous, very small, round calcar tubercle; no outer tarsal tubercles detectable; inner tarsal fold not detectable.

\section{Colour of holotype in life (see Fig. 8)}

Dorsal background colouration vivid yellow, top of head greyish brown; chocolate brown middorsal stripe and chocolate brown band on flanks; ill-defined, irregular reddish orange dorsolateral line; a few reddish orange blotches on the posterior part of the dorsum; a few reddish orange minute speckles on flanks; brown facemask; enlarged tubercle on eyelid whitish. Lower flanks yellow; groins, anterior thighs, and armpits brown. Arms and legs greyish brown with a few ill-defined white and dark yellow blotches. Ventral surfaces translucent greyish brown with a few irregular white spots and flecks; posterior surface of thighs and cloacal area brown. Upper face of hands and feet greyish brown with a few white and yellow markings; upper face of tip of fingers white; upper face of tip of Toes I-III white, brown on Toes IV-V. Palms, soles, undersurface of fingers and toes brown; discs greyish brown. Iris silver with dark brown venation and an ill-defined broad horizontal brownish stripe.

\section{Colour of Holotype in preservative (see Fig. 10)}

After 13 months in 70\% ethanol (July 2013). Vivid yellow faded to pale yellow. Chocolate brown and brown faded to light brown; top of head is dark brown; ill-defined white and dark yellow blotches on arms and legs are slightly more conspicuous and form irregular, ill-defined transverse bands; dorsal pattern turned generally more conspicuous. Ventral colouration is light grey with a few white spots and flecks. Granules in the cloacal area, as well as subarticular and supernumerary tubercles became dark brown. Discs are grey.

\section{Distribution and ecology}

Pristimantis imthurni sp. nov. is only known from the summit of Ptari-tepui (Figs 1B, 6B, 11), Bolívar state, Venezuela, where it occurs at $2471 \mathrm{~m}$ elevation. Ptari-tepui lies in the Ptari massif, in the Los Testigos subdistrict (McDiarmid \& Donnelly 2005). It is located ca. $47 \mathrm{~km}$ NE of the Chimantá massif, and $c a .22 \mathrm{~km}$ SE of Kamarkawarai-tepui (airline). According to the GPS, Ptari-tepui reaches a maximal elevation of about $2471 \mathrm{~m}$ above sea level. The summit area of Ptari-tepui is $c a .1 \mathrm{~km}^{2}$ and is dominated by flat open rock surfaces and small islands of low meadow-like tepui vegetation (Huber 1995; Fig. 11B).

The male holotype - and single specimen collected - was found at night while calling partly concealed in the muddy soil in a small vegetation patch. A few other males were heard calling very sporadically from other small vegetation islands by day or night, but could not be located. Pristimantis imthurni sp. nov. 


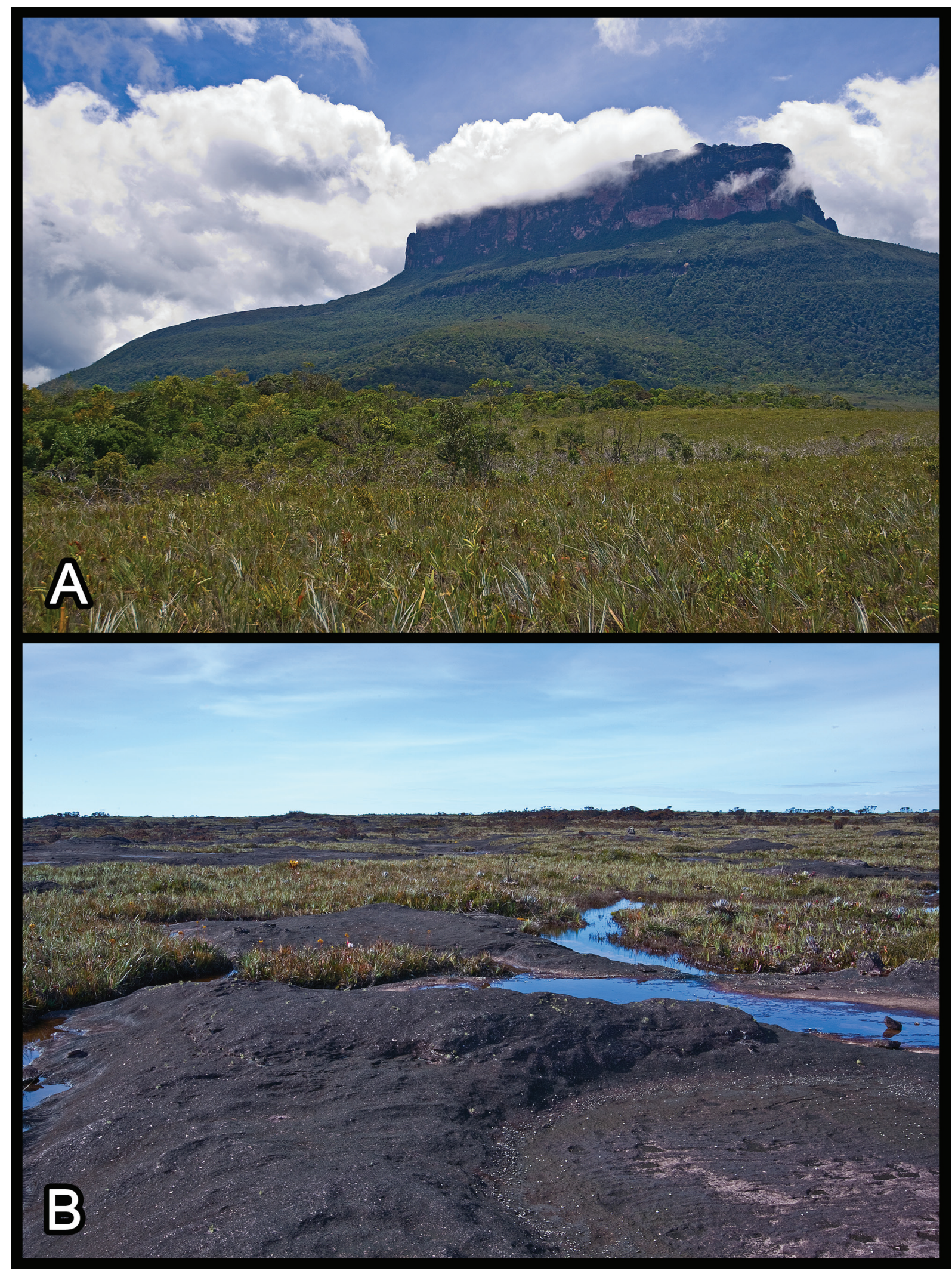

Fig. 11. A. Ptari-tepui, photographed from the surrounding savannah looking to the NE (21 Jun. 2012). B. Summit of Ptari-tepui (21 Jun. 2012). Photographs by the author. 
is not abundant. The only other anuran reported from the summit of Ptari-tepui is Tepuihyla rimarum Ayarzagüena, Señaris \& Gorzula, 1993, which apparently also occurs in low density (pers. obs.).

\section{Discussion}

Although Pristimantis imthurni sp. nov. and P. jamescameroni sp. nov. are not the geographically closest tepui summit species (both new species occur on very isolated tepui summits separated from each other by a distance of $c a .50 \mathrm{~km}$ airline), they are recovered as sister species in preliminary phylogenetic analyses based on mtDNA (pers. obs., August 2012). Unfortunately, the lack of genetic data from several tepui summit Pristimantis species (e.g., P. auricarens, P. muchimuk) prevents any concluding phylogenetic inferences at this point. It should be noted that DNA sequences of $P$. jamescameroni $\mathrm{sp}$. nov. have been used in previous molecular phylogenies under the name "Pristimantis sp" (Hedges et al. 2008) and "Pristimantis sp Aprada" (Kok et al. 2012), both confirming the generic allocation of the species.

McDiarmid \& Donnelly (2005) listed no less than 20 undescribed Pristimantis species from the Guiana Shield highlands (under the genus name Eleutherodactylus, from sp. A to T). Since that publication, only five of these 20 species have been named: Pristimantis sp. C from Auyán-tepui was described as $P$. auricarens by Myers \& Donnelly in 2008, P. sp. E from Yuruaní-tepui was described as $P$. yuruaniensis by Rödder \& Jungfer in 2008, $P$. sp. G from Sarisariñama-tepui was described as $P$. sarisarinama by BarrioAmorós \& Brewer-Carías in 2008, P. sp. S from Guaiquinima-tepui was described as $P$. guaiquinimensis by Schlüter \& Rödder in 2007, and $P$. sp. T from Cerro Marahuaka was described as P. marahuaka by Fuentes-Ramos \& Barrio-Amorós in 2004 (thus slightly before the opus of McDiarmid \& Donnelly was published). Three new species, not listed in McDiarmid \& Donnelly (2005), were recently described from additional localities (P. abakapa, P. aureoventris, and P. muchimuk). The present paper describes two of the still unnamed species listed in McDiarmid \& Donnelly (2005), P. sp. B and P. sp. H, still leaving 13 species to be named from the Pantepui region. Ten of these species occur in the Amazonas state of Venezuela (seven are reported from Cerro La Neblina, a huge massif located at the border with Brazil), three are from tepuis in the Bolívar state of Venezuela (the descriptions of two of them being in progress, Barrio-Amorós, pers. comm.).

The number of described Pristimantis species occurring exclusively on tepui (and faunistically related granitic mountains) summits and upper slopes now reaches eleven.

Although there is currently no evidence of continuing decline, given their apparent very restricted ranges ( $c a .1 \mathrm{~km}^{2}$ for Pristimantis imthurni sp. nov., less than $5 \mathrm{~km}^{2}$ for $P$. jamescameroni sp. nov.) and the reported sensitivity of tepui ecosystems to global warming (see Nogue et al. 2009), it is suggested that Pristimantis imthurni sp. nov. and P. jamescameroni sp. nov. be classified as "Endangered" (EN) in accordance with criteria B1 a-b (iii) and B2 a-b (iii) of the IUCN Red List of Threatened Species (2001).

\section{Acknowledgements}

The partial financial support of the non-profit organisation "les Amis de l'Institut Royal des Sciences Naturelles" is acknowledged. I thank B. Wilson (Atlanta, USA) for field companionship and C. BrewerCarías (Caracas, Venezuela) for invaluable help with logistics in Venezuela and useful clarifications about some tepui names. I also thank B. Means (Coastal Plains Institute and Land Conservancy, Florida, USA) for the gift of comparative material, and the following persons who loaned specimens from their respective institutions or provided access to comparative museum specimens and working space during my visit: B. Clarke and C. McCarthy (BMNH), R. Ernst (SNSD), and A. Schlüter (SMNS). The author was granted a postdoctoral fellowship from the Fonds voor Wetenschappelijk Onderzoek Vlaanderen (FWO12A7614N). 


\section{References}

Barrio-Amorós C.L. \& Brewer-Carías C. 2008. Herpetological results of the 2002 expedition to Sarisariñama, a tepui in Venezuelan Guayana, with the description of five new species. Zootaxa 1942: $1-68$.

Barrio-Amorós C.L., Mesa J., Brewer-Carías C. \& McDiarmid R.W. 2010. A new Pristimantis (Anura, Terrarana, Strabomantidae) from Churi-tepui in the Chimanta massif, Venezuelan Guayana. Zootaxa 2483: 35-44.

Berry P.E., Huber O. \& Holst B.K. 1995. Floristic analysis and phytogeography. In: Berry P.E., Holst B.K. \& Yatskievych K. (eds) Flora of the Venezuelan Guayana. Volume 1. Introduction: 161-192. Missouri Botanical Garden Press, St Louis.

Davis S.D., Heywood V.H. \& Hamilton A.C. 1997. Centres of Plant Diversity: A Guide and Strategy for their Conservation, Volume 3, The Americas. IUCN Publications Unit, Cambridge.

Dalziell R. 2007. Everard im Thurn in British Guiana and the western Pacific. In: Hulme P. \& McDougall R. (eds.) Writing, Travel and Empire: 97-116. I.B. Tauris \& Co. Ltd, London.

Doyle A.C. 1912. The Lost World. Hodder \& Stoughton, London.

Duellman W.E. \& Lehr E. 2009. Terrestrial-breeding Frogs (Strabomantidae) in Peru. NTV Science, Münster.

Frost D.R. 2013. Amphibian Species of the World: an Online Reference. Version 5.5 (9 Jan. 2013). American Museum of Natural History, New York [online]. Available from http://research.amnh.org/ herpetology/amphibia/index.php [accessed 20 Jul. 2013].

Fuentes-Ramos O. \& Barrio-Amorós C.L. 2004. A new Eleutherodactylus (Anura, Leptodactylidae) from Marahuaka Tepui, Amazonas, Venezuela. Revista de la Academia Colombiana de Ciencias Exactas, Físicas y Naturales 28: 285-290.

Gorzula S. \& Señaris J.C. 1999 "1998”. Contribution to the herpetofauna of the Venezuelan Guayana. I. A data base. Scientia Guaianae 8: 1-269.

Hedges S.B., Duellman W.E. \& Heinicke M.P. 2008. New World direct-developing frogs (Anura: Terrarana): Molecular phylogeny, classification, biogeography, and conservation. Zootaxa 1737: 1-182.

Huber O. 1995. Geographical and physical features. In: Berry P.E., Holst B.K. \& Yatskievych K. (eds) Flora of the Venezuelan Guayana. Volume 1. Introduction: 1-61. Missouri Botanical Garden Press, St Louis.

IUCN 2001. IUCN Red List Categories and Criteria. Version 3.1. Available from http://www.iucnredlist. org/technical-documents/categories-and-criteria/2001-categories-criteria [accessed 20 Jul. 2013].

Jungfer K.-H., Faivovich J., Padial J.M., Castroviejo-Fisher S., Lyra M., Von Muller Berneck B., Iglesias P., Kok P.J.R., MacCulloch R.D., Rodrigues M.T., Verdade V.K., Torres Gastello C.P., Chaparro J.C., Valdujo P.H., Reichle S., Moravec J., Gvozdík V., Gagliardi-Urrutia G., Ernst R., De La Riva I., Means D.B., Lima A.P., Señaris J.C., Wheeler W. \& Haddad C.F.B. 2013. Systematics of spiny-backed treefrogs (Hylidae: Osteocephalus): an Amazonian puzzle. Zoologica Scripta 42: 351-380. http://dx.doi. org/10.1111/zsc. 12015

Kok P.J.R. 2013. Islands in the Sky: Species Diversity, Evolutionary History, and Patterns of Endemism of the Pantepui Herpetofauna. $\mathrm{PhD}$ thesis, Leiden University, The Netherlands.

Kok P.J.R. \& Barrio-Amorós C.L. 2013. On the taxonomic validity of Pristimantis tepuiensis (Schlüter \& Rödder, 2007) and P. stegolepis (Schlüter \& Rödder, 2007), with remarks on the type series of $P$. 
guaiquinimensis (Schlüter \& Rödder, 2007). Zootaxa 3694(1): 75-80. http://dx.doi.org/10.11646/ zootaxa.3694.1.6

Kok P.J.R. \& Kalamandeen M. 2008. Introduction to the taxonomy of the amphibians of Kaieteur National Park, Guyana. Abc Taxa 5: 1-278.

Kok P.J.R., MacCulloch R.D., Means D.B., Roelants K., Van Bocxlaer I. \& Bossuyt F. 2012. Low genetic diversity in tepui summit vertebrates. Current Biology 22(15): 589-590 + supplementary information. http://dx.doi.org/10.1016/j.cub.2012.06.034

Kok P.J.R, Means D.B. \& Bossuyt F. 2011. A new highland species of Pristimantis Jiménez de la Espada, 1871 (Anura: Strabomantidae) from the Pantepui region, northern South America. Zootaxa 2934: 1-19.

Kok P.J.R., Willaert B. \& Means D.B. 2013. A new diagnosis and description of Anomaloglossus roraima (La Marca, 1998) (Anura: Aromobatidae: Anomaloglossinae), with description of its tadpole and call. South American Journal of Herpetology 8(1): 29-45. http://dx.doi.org/10.2994/SAJH-D-12-00021.1

Lynch J.D. \& Duellman W.E. 1997. Frogs of the genus Eleutherodactylus (Leptodactylidae) in Western Ecuador: Systematics, Ecology and Biogeography. University of Kansas Natural History Museum, Special Publication 23: 1-236.

Lynch J.D. \& Hoogmoed M.S.H. 1977. Two new species of Eleutherodactylus (Amphibia, Leptodactylidae) from northeastern South America. Proceedings of the Biological Society of Washington 90: 424-439.

Mägdefrau H. \& Mägdefrau K. 1994. Biologie von Anuren auf Tepuis der Roraima-Gruppe in Venezuela. In: Herrmann H.-J. \& Zimmermann H. (eds) Beiträge zur Biologie der Anuren: 84-102. Tetra Werke, Melle.

Mayr E. \& Phelps Jr. W.H. 1967. The origin of the bird fauna of the South Venezuelan highlands. Bulletin of the American Museum of Natural History 136: 269-328.

McDiarmid R.W. \& Donnelly M.A. 2005. The herpetofauna of the Guayana Highlands: amphibians and reptiles of the Lost World. In: Donnelly M.A., Crother B.I., Guyer C., Wake M.H. \& White M.E. (eds) Ecology and Evolution in the Tropics: A Herpetological Perspective: 461-560. University of Chicago Press, Chicago.

Means D.B. \& Savage J.M. 2007. Three new malodorous rainfrogs of the genus Pristimantis (Anura: Brachycephalidae) from the Wokomung Massif in west-central Guyana, South America. Zootaxa 1658: $39-55$.

Myers C.W. \& Donnelly M.A. 2008. The summit herpetofauna of Auyantepui, Venezuela: report from the Robert G. Goelet American Museum-Terramar Expedition. Bulletin of the American Museum of Natural History 308: 1-147. http://dx.doi.org/10.1206/308.1

Nogué S., Rull V. \& Vegas-Vilarrúbia T. 2009. Modeling biodiversity loss by global warming on Pantepui, northern South America: projected upward migration and potential habitat loss. Climatic Change 94:77-85. http://dx.doi.org/10.1007/s10584-009-9554-x

Pyron R.A. \& Wiens J.J. 2011. A large-scale phylogeny of Amphibia with over 2,800 species, and a revised classification of extant frogs, salamanders, and caecilians. Molecular Phylogenetics and Evolution 61: 543-583. http://dx.doi.org/10.1016/j.ympev.2011.06.012

Rödder D. \& Jungfer K-H. 2008. A new Pristimantis (Anura, Strabomantidae) from Yuruani-tepui, Venezuela. Zootaxa 1814: 58-68.

Rojas-Runjaic F.J.M., Salerno P.E., Señaris J.C. \& Pauly G.B. 2013. Terraranans of the Lost World: a new species of Pristimantis (Amphibia, Craugastoridae) from Abakapá-tepui in the Chimantá massif, 
Venezuelan Guayana, and additions to the knowledge of P. muchimuk. Zootaxa 3686(3): 335-355. http:// dx.doi.org/10.11646/zootaxa.3686.3.3

Rull V. \& Nogué S. 2007. Potential migration routes and barriers for vascular plants of the Neotropical Guyana Highlands during the Quaternary. Journal of Biogeography 34: 1327-1341. http://dx.doi. org/10.1111/j.1365-2699.2006.01602.x

Savage J.M., Hollingsworth B.D., Lips K.R. \& Jaslow A.P. 2004. A new species of rainfrog (genus Eleutherodactylus) from the Serranía de Tabasará, west-central Panama and reanalysis of the fitzingeri species group. Herpetologica 60(4): 519-529. http://dx.doi.org/10.1655/03-29

Schlüter A. \& Rödder D. 2007. Three new frogs of the genus Eleutherodactylus (Amphibia, Leptodactylidae) from Guaiquinima Table Mountain, Bolívar, Venezuela. Herpetotropicos 3: 88-99.

Steyermark J.A. 1982. Relationships of some Venezuelan forest refuges with lowland tropical floras. In: Prance G.T. (ed.) Biological Diversification in the Tropics: 182-220. Columbia University Press, New York.

Manuscript received: 5 August 2013

Manuscript accepted: 27 September 2013

Published on: 22 October 2013

Topic editor: Rudy Jocqué

Desk editor: Kristiaan Hoedemakers

Printed versions of all papers are also deposited in the libraries of the institutes that are members of the EJT consortium: Muséum National d'Histoire Naturelle, Paris, France; National Botanic Garden of Belgium, Meise, Belgium; Royal Museum for Central Africa, Tervuren, Belgium; Natural History Museum, London, United Kingdom; Royal Belgian Institute of Natural Sciences, Brussels, Belgium; Natural History Museum of Denmark, Copenhagen, Denmark.

\section{Appendix: Additional material examined}

Pristimantis abakapa: VENEZUELA, Estado Bolívar, Abakapá-tepui, IRSNB 15868 (topotypic specimen).

Pristimantis aureoventris: GUYANA, Cuyuni-Mazaruni District, Wei-Assipu-tepui, IRSNB 4152 (holotype), IRSNB 4153-54 (paratopotypes).

Pristimantis dendrobatoides: GUYANA, Potaro-Siparuni District, Wokomung Massif, IRSNB 15918 (topotypic specimen).

Pristimantis jester: GUYANA, Cuyuni-Mazaruni District, slopes of Maringma-tepui, IRSNB 15867, IRSNB 15916-17.

Pristimantis marmoratus: GUYANA, Cuyuni-Mazaruni District, foot of Mount Roraima, BMNH 1947.2.16.92 (formerly 99.3.25.19) (holotype).

Pristimantis pulvinatus: VENEZUELA, Estado Bolívar, La Escalera, IRSNB 15654.

Pristimantis saltissimus: GUYANA, Potaro-Siparuni District, Wokomung Massif, IRSNB 15644-53 (topotypic specimens).

Pristimantis yuruaniensis: VENEZUELA, Estado Bolívar, Yuruaní Tepui, IRSNB 15638-41 (topotypic specimens), SMNS 09855 (paratype). 